\title{
VARIOUS CONCENTRATION DISTRIBUTION OF BENZIL AMINO PURINE CONCENTRATIONS ON CALLUS GROWTH IN APPLE CUCUMBER ORIGINATED FROM KARAWANG
}

\author{
Liga Nursolihah*, Slamet Abadi, Nurcahyo Widyodaru Saputro \\ Program Studi Agroteknologi Fakultas Pertanian, Universitas Singaperbangsa Karawang \\ Jl. H.S. Ronggowaluyo Kel. Puseurjaya, Kecamatan Telukjambe Timur, \\ Kabupaten Karawang, Prov. Jawa Barat, Indonesia \\ *liganursolihah@gmail.com
}

Doi: https://doi.org/10.31943/mangiferaedu.v6i2.120

Received: February 10, 2021 Accepted: January 26, 2022 Published: January 31, 2022

Citation: Nursilihah, L., Abadi, S., \& Saputro, N.W. (2022). Various Concentration Distribution of Benzil Amino Purine Concentrations on Callus Growth in Apple Cucumber Originated from Karawang. Jurnal Mangifera Edu, 6(2), 139152.

\begin{abstract}
Apple cucumber have relatives with melon as seen from squencing using the Internal Transribed Spacer (ITS) method. The lack of data regarding the morphology of the apple cucumber causes the absence of information on the morpho-agronomy of the apple cucumber. The purpose of the study is to find the best Benzil Amino Purine (BAP) concentrations and proper explants for the growth of the apple cucumber callus (Cucumis sp.) on Murashige and Skoog (MS) media. Research on direct of part apple cucumber was conducted from March until May 2019. The methods used was an experimental method with non parametric statistic with 8 treatments: $A_{0} B_{1}(B A P 0+$ Leaves $), A_{0} B_{2}(B A P 0+$ Stem), $A_{1} B_{1}\left(B A P 0.5 \mu M+\right.$ Leaf), $A_{1} B_{2}(B A P 0.5 \mu M+$ Stem $), A_{2} B_{1}\left(B A P 1.5 \mu M+\right.$ Leaf), $A_{2} B_{2}$ (BAP $1.5 \mu M+$ Stem), $A_{3} B_{1}$ (BAP $3.0 \mu M+$ Leaves) and $A_{3} B_{2}$ (BAP $3.0 \mu M+$ Stems) that were repeated 5 times and analyzed descriptively using the Kruskal Wallis Test. The results showed that callus growth of apple cucumber at the best concentartion BAP and exsplant that is at concentration $0.5 \mu M B A P+$ stem which exerted a faster effect on callus formation time (27 hsi), $1.5 \mu \mathrm{M} \mathrm{BAP}+$ stem giving the largest diameter with $1.2 \mathrm{~cm}$ with crumb and yellowish-green morphology. The stem explant gives the best growth rate $(0.887 \mathrm{~cm} / 3$ day) on $0.5 \mu M$ and $1.5 \mu M$ concentration.
\end{abstract}

Keywords: BAP, Callus, Concentration, Explant

\section{ABSTRAK}

Timun apel memiliki kerabat dengan melon dilihat dari squensing dengan metode Internal Transribed Spacer (ITS). Kurangnya data mengenai morfologi timun apel menyebabkan tidak adanya informasi mengenai morfo-agronomi pada timun apel. Penelitian ini bertujuan untuk mendapatkan konsentrasi Benzil Amino Purine (BAP) dan eksplan yang tepat untuk pertumbuhan kalus timun apel (Cucumis sp.) pada media Murashige dan Skoog (MS). Penelitian tentang kalus timun apel langsung pada bagian tanaman timun apel telah dilaksanakan pada bulan Maret sampai Mei 2019. Metode yang digunakan yaitu eksperimental dengan statistik non parametrik dengan 8 perlakuan yaitu $A_{0} B_{1}\left(B A P 0+\right.$ Daun), $A_{0} B_{2}\left(B A P 0+\right.$ Batang), $A_{1} B_{1}(B A P 0.5 \mu M+$ Daun $), A_{1} B_{2}(B A P 0.5$ $\mu M+$ Batang), $A_{2} B_{1}\left(B A P 1.5 \mu M+\right.$ Daun), $A_{2} B_{2}\left(B A P 1.5 \mu M+\right.$ Batang), $A_{3} B_{1}(B A P 3.0$ 
$\mu M+$ Daun $)$ dan $A_{3} B_{2}(B A P 3.0 \mu M+$ Batang) yang diulang sebanyak 5 kali serta dianalisis secara deskripif menggunakan Uji Kruskal Wallis. Hasil penelitian menunjukkan bahwa pertumbuhan kalus timun apel pada konsentrasi terbaik BAP dan eksplan yaitu pada konsentrasi $0.5 \mu M$ BAP + batang dapat menghasilkan waktu muncul kalus pada 27 hsi, konsentrasi $1.5 \mu M B A P$ + batang menghasilkan diameter sebesar $1.2 \mathrm{~cm}$ dengan morfologi remah dan berwarna hijau kekuingan, sedangkan untuk laju pertumbuhan eksplan batang dengan konentrasi $0.5 \mu \mathrm{M}$ dan $1.5 \mu \mathrm{M}$ menghasilkan $0.462 \mathrm{~cm} / 3$ hari dan $0.887 \mathrm{~cm} / 3$ hari.

Keywords: BAP, Kallus, Koncentration, Explan

\section{PENDAHULUAN}

Indonesia merupakan negara yang mempunyai kekayaan alam yang melimpah, salah satunya adalah sektor hortkultura. Sektor ini memiliki prospek yang bagus untuk dikembangkan, salah satunya adalah timun apel yang dibudidayakan di Karawang. Menurut Mustikawaty \& Saputro, (2021) menyatakan bahwa timun apel memiliki kerabat dengan melon dilihat dari squensing dengan metode Internal Transribed Spacer (ITS). Kurangnya data mengenai morfologi timun apel menyebabkan tidak adanya informasi mengenai morfoagronomi pada timun apel.

Kultur jaringan memperbanyak tanaman unggul melalui reproduksi secara aseksual. Perbanyakan secara kultur jaringan (in vitro) merupakan suatu metode untuk mengisolasikan bagian tanaman seperti protoplas, sel, jaringan, dan organ sehingga bagian-bagian tersebut dapat memperbanyak diri dan beregenerasi menjadi tanaman lengkap kembali (Sandra, 2019). Menurut Heriansyah (2020), keberhasilan teknik ini dipengaruhi oleh beberapa faktor, diantaranya penggunaan bahan tanam (sumber eksplan), ketepatan penggunaan media, dan penambahan Zat Pengatur Tumbuh (ZPT). Eksplan menjadi syarat utama keberhasilan inisiasi. Bagian tanaman yang dapat dijadikan sumber eksplan adalah pucuk muda, batang muda, daun muda, kotiledon dan hipokotil (Uzun et.al., 2014). Menurut Noviati et al., (2012) menyatakan bahwa eksplan daun menghasilkan kalus dengan berat segar tertinggi dibandingkan dengan eksplan tangkai daun dan kelopak, selain itu penambahan ZPT dapat mendukung pertumbuhan suatu tanaman (Yuwono, 2012). Sitokinin merupakan contoh ZPT yang digunakan dalam kultur jaringan yang berperan untuk merangsang pembelahan sel (Imelda et al., 2008). Rendahnya laju pembelahan sel diharapkan bisa diatasi dengan penambahan sitokinin (Sudiyanti et al., 2017). Menurut Yusnita (2003), Benzil Amino Purin (BAP) merupakan ZPT sitokinin yang memiliki efektifitas untuk pertumbuhan dibandingkan dengan sitokinin lainnya, maka perlu dilakukan 
Jurnal Mangifera Edu, Volume 6, Issue 2, January 2022, 138-151

penelitian untuk mendapatkan konsentrasi ZPT dan eksplan yang tepat agar kalus dapat tumbuh dan berkembang melalui kultur jaringan pada media MS.

\section{METODOLOGI PENELITIAN}

Percobaan dilakukan di Laboratorium Bioteknologi Tanaman Fakultas Pertanian, Universitas Singaperbangsa Karawang yang berada di Jalan. H.S. Ronggowaluyo, Telukjambe Timur, Karawang, dengan titik koordinat 6 ${ }^{\circ} 19^{\prime} 21.46^{\prime \prime}$ LS dan 107¹8'24.05', BT serta ketinggian $23.3 \mathrm{~m}$ dpl. Bahan yang digunakan dalam percobaan ini adalah media MS, BAP, aquades steril, spirtus, alkohol 70\%, klorox, detergen, fungisida, bakkterisida, $\mathrm{NaOH} 1 \mathrm{~N}, \mathrm{HCl} 1 \mathrm{~N}$, sabun pencuci cair, agar, gula dan eksplan.

Metode penelitian yang digunakan dalam penelitian ini adalah metode eksperimental dengan 8 perlakuan yaitu $\mathrm{A}_{0} \mathrm{~B}_{1}$ (BAP $0+$ Daun), $\mathrm{A}_{0} \mathrm{~B}_{2}$ (BAP $0+$ Batang), $\mathrm{A}_{1} \mathrm{~B}_{1}$ (BAP 0.5 $\mu \mathrm{M}+$ Daun), $\mathrm{A}_{1} \mathrm{~B}_{2}$ (BAP $0.5 \mu \mathrm{M}+$ Batang), $\mathrm{A}_{2} \mathrm{~B}_{1}$ (BAP $1.5 \mu \mathrm{M}+$ Daun), $\mathrm{A}_{2} \mathrm{~B}_{2}$ (BAP 1.5 $\mu \mathrm{M}+$ Batang), $\mathrm{A}_{3} \mathrm{~B}_{1}$ (BAP $3.0 \mu \mathrm{M}+$ Daun) dan $\mathrm{A}_{3} \mathrm{~B}_{2}$ (BAP $3.0 \mu \mathrm{M}+$ Batang) dan diulang sebanyak lima kali dan dianalisis dengan secara deskriptif menggunakann Uji Kruskal Wallis.

1. Persiapan

Botol kultur direbus dalam panci selama 15 menit kemudian diangkat dan didiamkan hingga dingin. Botol yang telah dingin kemudian direndam dalam larutan klorox dan detergen selama 30 menit, kemudian dibilas dengan air mengalir sampai benar-benar bersih dan dikering anginkan (Hafizh et al., 2019). Peralatan pinset, scalpel, cawan petri, gelas ukur, erlenmeyer dan peralatan gelas lainnya dicuci dengan detergen kemudian direndam ke dalam larutan klorox selama 30 menit. Setelah itu, alat dikering anginkan, dibungkus menggunakan kertas sampul dan disterilisasi menggunakan autoklaf pada temperatur $121^{\circ} \mathrm{C}$ dengan tekanan 1.5 Pounds per Square Inch (psi) selama 15 menit.

2. Pembuatan Media dan Larutan Stok

Media yang digunakan adalah media MS. Langkah awal yaitu menimbang MS sebanyak 4.43 g. Air steril $500 \mathrm{ml}$ dimasukkan ke dalam erlenmeyer kapasitas 1000ml, kemudian larutan gula $30 \mathrm{~g}$ ditambahkan BAP sesuai dengan perlakuan kemudian diukur $\mathrm{pH}$ larutan 5.8 (Istiningdyah et al., 2013), ditambahkan air steril mencapai $1000 \mathrm{ml}$, pindahkan dalam bekker glass $1000 \mathrm{ml}$ lalu ditambahkan agar-agar 8g dan dipanaskan sampai mendidih sampai suhu $80^{\circ} \mathrm{C}$ dengan menggunakan hotplate magnetic stirer, selanjutnya dimasukkan ke dalam botol kultur. Botol kultur yang berisi media ditutup menggunakan penutup plastik 
Jurnal Mangifera Edu, Volume 6, Issue 2, January 2022, 138-151

dan disterilisasi dalam autoklaf pada temperatur $121^{\circ} \mathrm{C}$ dengan tekanan 1.5 psi selama 15 menit (Ardiana, 2009).

\section{Sterilisasi Ekplan}

Eksplan yang digunakan berupa daun dan batang timun apel. Eksplan dicuci diair mengalir kemudian direndam di dalam larutan fungisida dan bakterisida selama 15 menit dan dibilas menggunakan akuades. Sterilisasi eksplan dilakukan didalam Laminar Air Flow (LAF) dengan menggunakan larutan klorox 5\% dan $10 \%$ selama 3 menit. Urutan sterilisasi menggunakan klorox dilakukan dengan urutan yang paling rendah kemudian direndam 3 kali air steril (Indah \& Ermavitalini, 2013) dengan menggoyang-goyangkan, eksplan diambil dengan pinset dan ditiriskan pada cawan petri yang berisi kertas saring steril (Lugrasa \& Tirta, 2003).

\section{Penanaman}

Kegiatan penanaman dilakukan di dalam LAF yang telah dibersihkan dengan alkohol 70\%. Lampu ultraviolet (UV) diaktifkan 30 menit sebelum LAF digunakan (Pramono, 2014). Semua alat yang akan dimasukan ke dalam LAF disemprot dengan alkohol $70 \%$. Alat logam seperti pinset dan scalpel direndam ke dalam alkohol sebelum digunakan untuk memotong eksplan, lalu dipanaskan di atas bunsen yang menyala.

Eksplan diambil dan dipotong guna memperkecil adanya desinfektan yang terbawa dalam eksplan. Pemotongan diletakkan dicawan petri (Istiningdyah et al., 2013) kemudian ditanam ke dalam botol kultur yang telah berisi perlakuan dan ditutup menggunakan penutup. Seluruh kegiatan dilakukan dekat pembakar bunsen.

5. Pemeliharaan

Ruang kultur harus selalu dalam keadaan aseptik dan harus dibersihkan setiap hari. Lantai ruangan dipel menggunakan pembersih lantai, sedangkan botol-botol kultur yang berisi tanaman disemprot dengan alkohol $70 \%$ setiap tiga hari.

6. Pengamatan

a. Waktu Muncul Kalus

Pengamatan dilakukan setiap hari dengan menghitung hari saat muncul kalus pertama kali yang dinyatakan dalam hari setelah isolasi (hsi) yang ditandai dengan adanya pembengkakan atau munculnya jaringan berwarna putih kehijauan pada permukaan eksplan (Widiyastuti, 2015). 
Jurnal Mangifera Edu, Volume 6, Issue 2, January 2022, 138-151

b. Diameter Kalus

Pengamatan dilakukan selama 2 bulan dengan mengukur diameter kalus menggunakan penggaris mm, pengukuran dilakukan 4 garis diameter dan diambil rata-rata dari pengukuran tersebut (Risdianto et al., 2007).

c. Laju Pertumbuhan

Pengamatan dilakukan selama 2 bulan sejak penanaman dengan mengukur pertumbuhan menggunakan penggaris $\mathrm{cm} / \mathrm{hari}$.

Laju koloni pertumbuhan arah radial $=\frac{\mathbf{d}_{n}-\mathbf{d}_{\mathbf{0}}}{\mathbf{t}_{\mathbf{n}}-\mathbf{t}_{\mathbf{0}}}$

Keterangan:

$\mathrm{d}_{0}$ : Diameter rata-rata pada waktu awal

$\mathrm{d}_{n}$ : $\quad$ Diameter rata-rata pada waktu ke-n

$t_{0}$ : Waktu awal

$t_{n}: \quad$ Waktu akhir

Sumber: (Lestari, 2011)

d. Morfologi Kalus

Warna kalus merupakan suatu indikasi baik tidaknya kualitas dari kalus tersebut (Andaryani, 2010). Warna kalus mengindikasikan keberadaan klorofil dalam jaringan, semakin hijau warna kalus semakin banyak pula kandungan klorofilnya.

Tekstur kalus merupakan salah satu penanda yang digunakan untuk menilai kualitas kalus. Berdasarkan tekstur dan komposisi selnya, kalus dapat dibedakan menjadi kalus yang kompak dan remah. Kalus kompak mempunyai tekstur padat dan keras yang tersusun dari sel-sel kecil yang sangat rapat, sedangkan kalus remah mempunyai tekstur lunak dan tersusun dari sel-sel dengan ruang antar sel yang banyak (Sugiyarto \& Kuswandi, 2014).

\section{HASIL DAN PEMBAHASAN}

1. Saat Muncul Kalus

Salah satu indikator adanya pertumbuhan dalam kultur jaringan adalah munculnya kalus pada eksplan (Handoyowati, 2016). Selama masa inkubasi, kalus mulai muncul pada minggu ketiga. Data munculnya kalus seluruh perlakuan tersaji pada Tabel 1. 
Jurnal Mangifera Edu, Volume 6, Issue 2, January 2022, 138-151

Tabel 1. Pengaruh Pemberian BAP dan Eksplan Terhadap Waktu Pembentukan Kalus

\begin{tabular}{cccccccccc}
\hline Perlakuan & $\begin{array}{c}\text { BAP } \\
(\boldsymbol{\mu M})\end{array}$ & \multicolumn{2}{c}{$\mathbf{0 . 0}\left(\mathrm{A}_{\mathbf{0}}\right)$} & \multicolumn{2}{c}{$\mathbf{0 . 5}\left(\mathrm{A}_{\mathbf{1}}\right)$} & \multicolumn{2}{c}{$\mathbf{1 . 5}\left(\mathrm{A}_{2}\right)$} & \multicolumn{2}{c}{$\mathbf{3 . 0}\left(\mathrm{A}_{3}\right)$} \\
\hline & Eksplan & $\mathrm{D}$ & $\mathrm{B}$ & $\mathrm{D}$ & $\mathrm{B}$ & $\mathrm{D}$ & $\mathrm{B}$ & $\mathrm{D}$ & $\mathrm{B}$ \\
& $\left(\mathrm{B}_{1}\right)$ & $\left(\mathrm{B}_{2}\right)$ & $\left(\mathrm{B}_{1}\right)$ & $\left(\mathrm{B}_{2}\right)$ & $\left(\mathrm{B}_{1}\right)$ & $\left(\mathrm{B}_{2}\right)$ & $\left(\mathrm{B}_{1}\right)$ & $\left(\mathrm{B}_{2}\right)$ \\
$\begin{array}{c}\text { Hari ke- } \\
\text { (hsi) }\end{array}$ & & - & 54 & 33 & 27 & & 36 & - & - \\
\hline
\end{tabular}

Keterangan: (-) kalus belum muncul, D: Daun, B: Batang

Tabel 1 menunjukan bahwa dari seluruh perlakuan terdapat tiga perlakuan yang berhasil menumbuhkan kalus. Pertumbuhan kalus diawali dengan pembengkakan pada eksplan (Widiyastuti, 2015) dan diikuti dengan munculnya kalus yang berwarna hijau.

Kalus mulai muncul pada perlakuan $0.5 \mu \mathrm{M}$ BAP + eksplan batang dihari ke-27 hsi dan merupakan perlakuan yang mampu menumbuhkan kalus paling cepat, diduga pada eksplan batang terkandung ZPT endogen sehingga mencapai keseimbangan (Argaloka, 2013). Keseimbangan ZPT terjadi karena konsentrasi ZPT endogen yang terdapat pada eksplan dan ZPT/eksogen yang ditambahkan pada eksplan sehingga dengan konsentrasi rendah yang dipakai telah cukup mampu menghasilkan kalus lebih cepat dibandingkan dengan konsentrasi yang lain. Pemberian sitokinin (BAP) eksogen dibutuhkan eksplan dalam kondisi rendah untuk menginduksi kalus. Hal ini sesuai dengan hasil penelitian (Ramdan et al., 2014) yang menjelaskan bahwa konsentrasi sitokinin rendah (0.5mg/l) mampu menginduksi kalus Citrus rootstock yang paling cepat yaitu 8 hsi.

Perlakuan $1.5 \mu \mathrm{M}$ BAP + eksplan batang memunculkan kalus pada 36 hsi dan yang menumbuhkan kalus paling lambat yaitu pada perlakuan $0 \mu \mathrm{M}$ BAP + eksplan batang pada 54 hsi. Perbandingan konsentrasi dan interaksi ZPT yang diberikan ke dalam media dan yang diproduksi oleh sel secara endogen akan menentukan arah perkembangan suatu kultur, sehingga setiap eksplan yang ada akan memberikan respon yang berbeda bergantung pada level hormon yang ada (Srikandarajah et al., 2006). Penggunaan BAP pada konsentrasi yang tepat sangat efektif merangsang penggandaan kalus (George, 1993), selain itu perbedaan bagian yang digunakan akan menghasilkan pola pertumbuhan yang berbeda (Wattimena, 1992: Mardhiyeti, 2015).

Respon eksplan terhadap pemberian BAP berbeda dan menumbuhkan kalus sebanyak 6 dari 40 unit percobaan. Kalus tidak tumbuh karena kombinasi ZPT pada medium belum mampu menginduksi kalus (Indah \& Ermavitalini, 2013) atau kalus tidak tumbuh karena ZPT endogen dan eksogen yang terdapat di dalam eksplan tidak dapat merangsang pertumbuhan kalus dengan cepat (Indah \& Ermavitalini, 2013). 
Jurnal Mangifera Edu, Volume 6, Issue 2, January 2022, 138-151

Ketidakmunculan kalus disebabkan karena pada jaringan eksplan tidak memiliki informasi dan perangkat fisiologis yang lengkap sehingga tidak dapat memasuki siklus pembelahan sel, padahal BAP sendiri termasuk ke dalam golongan sitokinin yang berfungsi untuk pembelahan sel dan dapat memacu pertumbuhan kalus dan tunas (Harjadi, 2009) akan tetapi, pada eksplan timun apel peran BAP dalam memacu pertumbuhan kalus kurang optimal sehingga kalus yang terbentuk sedikit.

2. Diameter Kalus

Pengukuran diameter dilakukan setelah 27 hsi. Berdasarkan hasil uji Kruskal Wallis diperoleh hasil seperti yang dicantumkan pada Tabel 2.

Tabel 2 Hasil Nilai H pada setiap hsi

\begin{tabular}{cccc}
\hline hsi & Nilai $\mathbf{H}$ & Tabel Chi Square & Kesimpulan $\mathbf{H}_{\mathbf{0}}$ \\
\hline 27 & 1.390 & 3.841 & diterima \\
30 & 0.330 & 3.841 & diterima \\
33 & 6.355 & 5.991 & ditolak \\
36 & 8.735 & 5.991 & ditolak \\
39 & 3.242 & 5.991 & diterima \\
42 & 3.242 & 5.991 & diterima \\
45 & 3.242 & 5.991 & diterima \\
48 & 1.384 & 5.991 & diterima \\
51 & 7.080 & 5.991 & ditolak \\
54 & 7.080 & 5.991 & ditolak \\
\hline
\end{tabular}

Keterangan:

Tabel Chi square pada $5 \%$

$\mathrm{H}>$ tabel chi square maka $\mathrm{H}_{0}$ ditolak, $\mathrm{H}<$ tabel

chi square maka $\mathrm{H}_{0}$ diterima

Nilai H yang diperoleh pada 27 hsi dan 30 hsi yaitu sebesar 1.390 dan 0.330 jika dibandingkan dengan nilai tabel chi square, jika nilai $\mathrm{H}<$ tabel chi square maka dapat dikatakan bahwa $\mathrm{H}_{0}$ diterima atau tidak ada pertumbuhan diameter kalus pada tanaman timun apel. pada 33, 36, 51 dan 54 hsi sebesar 6.355, 8.735, 7.080 dan 7.080 pertumbuhan diameter bisa dikatakan sama. pada 39 hsi, 42 hsi, 45 hsi dan 48 hsi, nilai $\mathrm{H}<$ tabel chi square maka $\mathrm{H}_{0}$ diterima, artinya pada hsi tersebut tidak terjadi pertumbuhan diameter kalus tanaman timun apel. Rata-rata pertumbuhan diameter kalus timun apel dapat dilihat pada Gambar 1. 


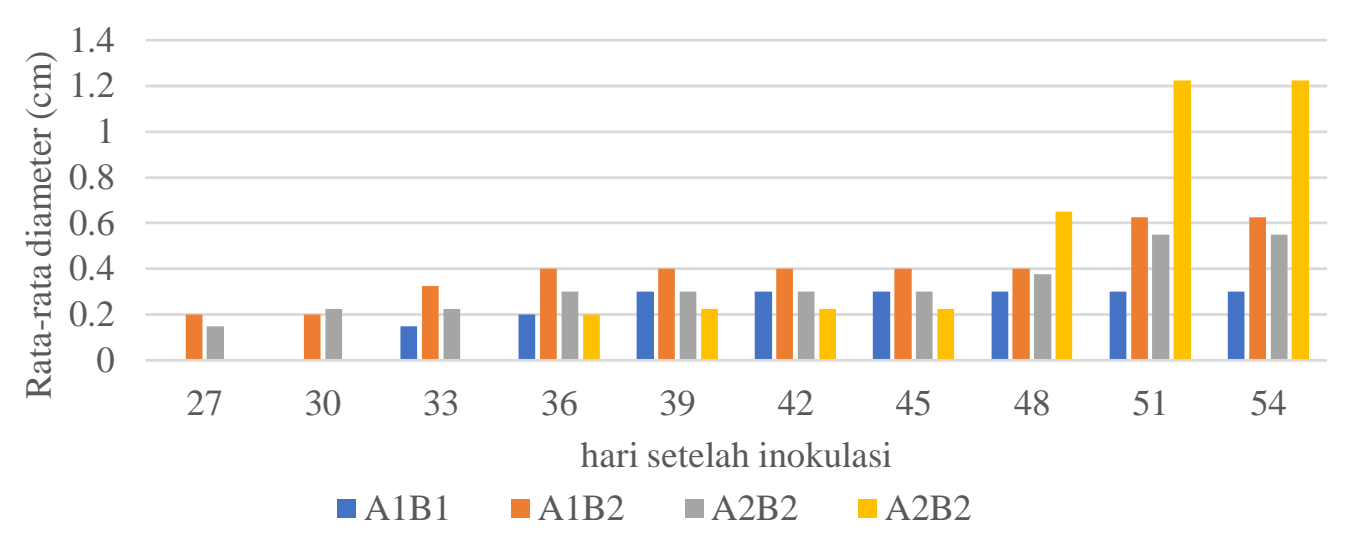

\section{Gambar 1. Rata-Rata Pertumbuhan Diameter Kalus}

Gambar 1 menunjukkan bahwa pertumbuhan diameter perlakuan $\mathrm{A}_{2} \mathrm{~B}_{2}$ merupakan perlakuan yang menghasilkan pertumbuhan diameter yang paling tinggi. Hasil penelitian (Damanik \& Siregar, 2017) menyebutkan bahwa eksplan batang merupakan eksplan terbaik pada pembentukan kalus binahong (Anredera cordifolia Ten Steenis) dengan penambahan BAP $0.5-1 \mathrm{mg} / 1$.

Pada dasarnya perubahan diameter kalus menunjukkan eksplan yang ditanam masih hidup (Toharah et al., 2015). Ukuran kalus yang dihasilkan setiap media perlakuan berbedabeda, hal ini disebabkan oleh kemampuan jaringan dalam menyerap air dan unsur hara (Sriyanti, 2000). Menurut (Muliati et al., 2017) menyebutkan bahwa penggunaan BAP pada konsentrasi yang tepat sangat efektif merangsang penggandaan kalus dan tunas karena penambahan BAP dalam media perbayakan in vitro berperan aktif dalam organogenesis secara alami. BAP merupakan salah satu golongan sitokinin yang dapat memacu dan menginduksi kalus akan tetapi, jenis dan konsentrasinya bergantung pada jenis tanaman.

3. Laju Pertumbuhan

Laju pertumbuhan dianalisis berdasarkan data diameter kalus timun apel yang terbentuk dan dapat dilihat pada Gambar 2.

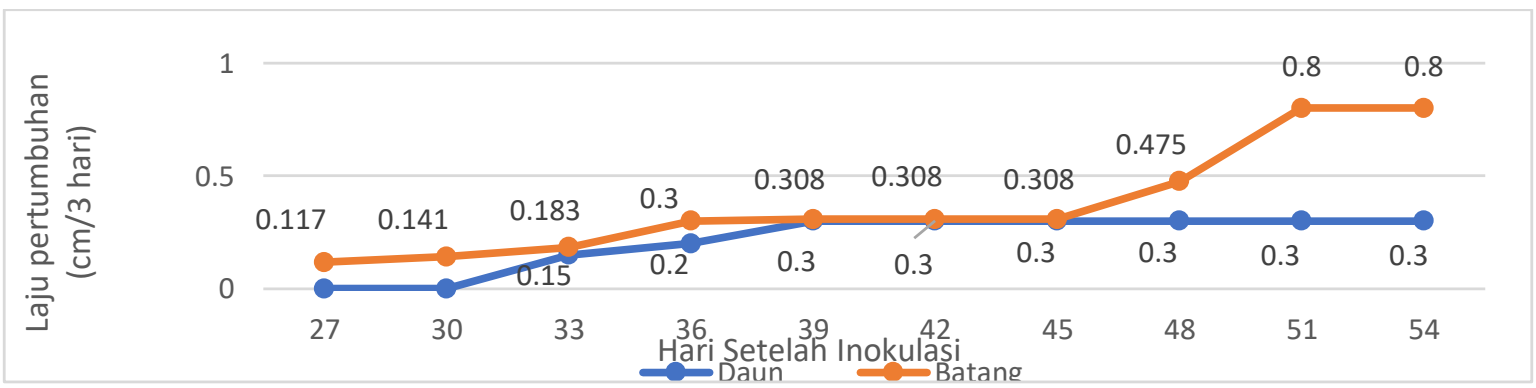

Gambar 2 Laju Pertumbuhan Eksplan Timun Apel 
Jurnal Mangifera Edu, Volume 6, Issue 2, January 2022, 138-151

Gambar 2 menjelaskan bahwa laju pertumbuhan tercepat ditunjukkan oleh eksplan batang pada saat 51 dan 54 hsi sebesar $0.800 \mathrm{~cm} / 3$ hari. Menurut Junairiah et al. (2019) menyebutkan bahwa perbedaan laju pertumbuhan dipengaruhi oleh kepekaan sel dalam merespon ZPT, waktu pembelahan sel untuk memperbanyak diri tidak sama karena siklus selnya akan selalu berbeda-beda dan kemampuan jaringan untuk menyerap zat-zat hara yang tersedia. Laju pertumbuhan setiap perlakuan berbeda-beda dan dapat dilihat pada Gambar 3, 4 dan 5.

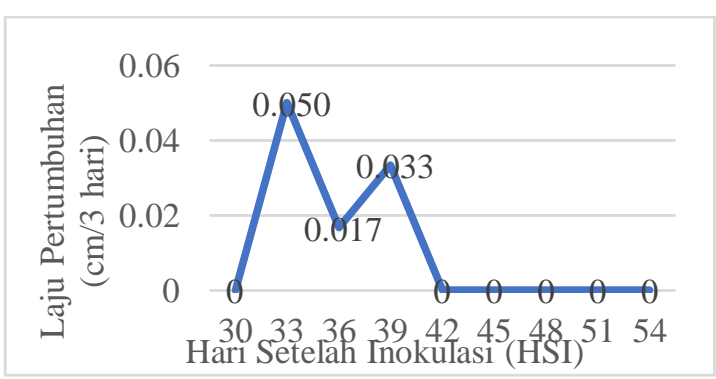

Gambar 3 Laju Pertumbuhan Perlakuan $\mathrm{A}_{1} \mathrm{~B}_{1}$

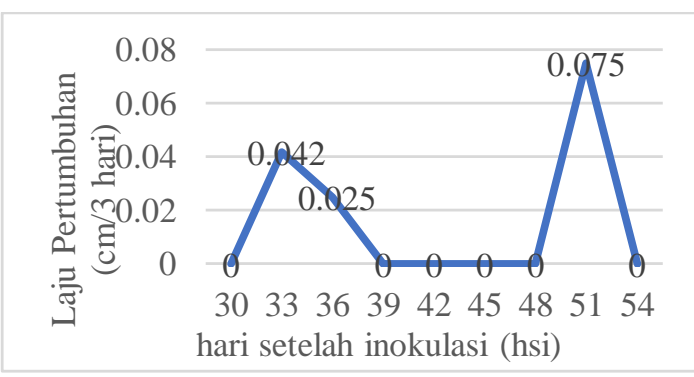

Gambar 4 Laju Pertumbuhan Perlakuan $\mathrm{A}_{1} \mathbf{B}_{2}$

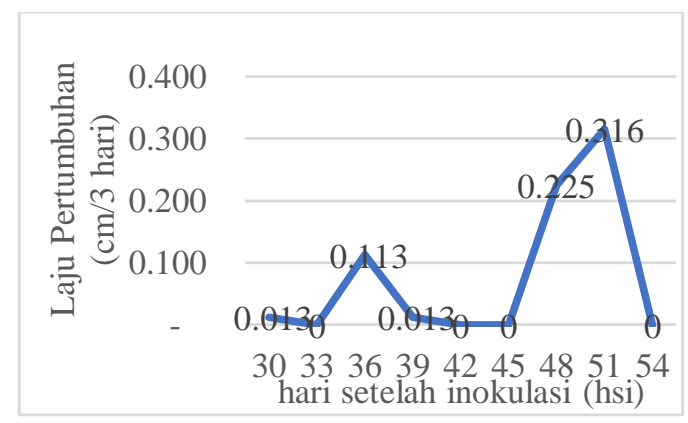

Gambar 5 Laju Pertumbuhan Perlakuan $A_{2} B_{2}$

Setiap perlakuan memiliki laju pertumbuhan yang berbeda selama 54 hsi dan mengalami fluktuasi. Hal ini diduga disebabkan oleh ada tidaknya keseimbangan ZPT di dalam eksplan, sehingga terjadi perbedaan penyerapan dalam media (Sriyanti, 2000). Menurut Sugiyama (1999) menyebutkan bahwa dalam kultur in vitro sel ada jaringan eksplan harus memiliki sifat kompeten. Kompeten merupakan kemampuan dari sel atau jaringan untuk merespon sinyal dari ZPT yang ditambahkan sehingga sel atau jaringan dapat berkembang. Perbedaan laju pertumbuhan kalus pada eksplan daun ataupun batang dapat dipengaruhi oleh konsentrasi BAP yang ditambahkan (Rahayu \& Mardini, 2015). Pada penelitian ini bisa dikatakan bahwa perlakuan yang paling tinggi untuk laju pertumbuhan kalus timun apel yaitu pada perlakuan $\mathrm{A}_{2} \mathrm{~B}_{2}$ sebesar $0.316 \mathrm{~cm} / 3$ hari. Adapun laju pertumbuhan setiap konsentrasi dapat dilihat pada Gambar 6. 


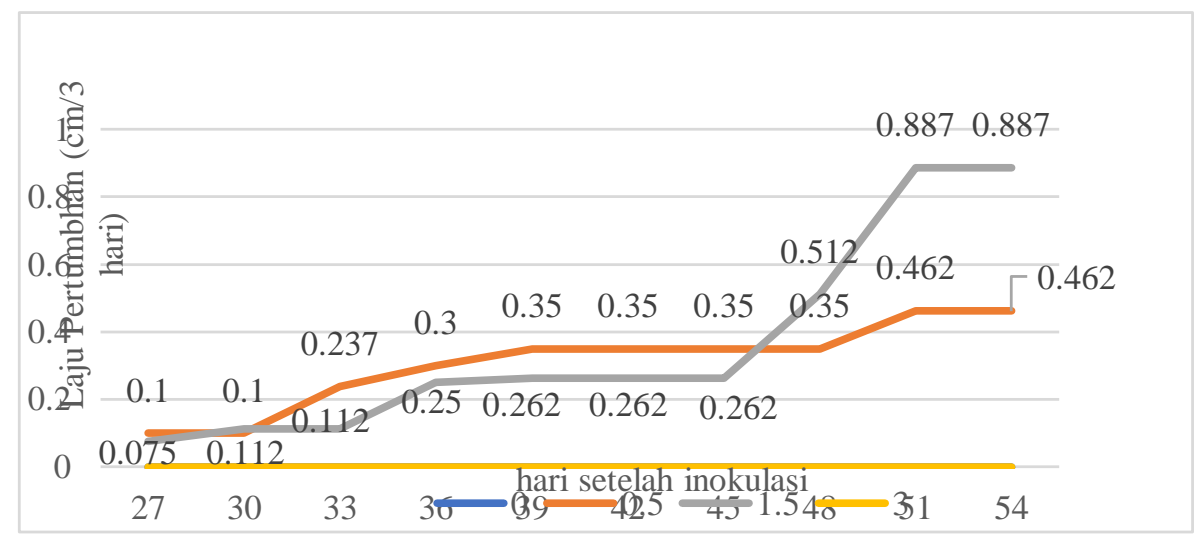

Gambar 6 Laju Pertumbuhan Setiap Konsentrasi

Gambar 6 menunjukkan bahwa konsentrasi 0 dan $3 \mu \mathrm{M}$ memiliki laju pertumbuhan sebesar $0 \mathrm{~cm} / 3$ hari. Hal ini disebabkan karena kalus tidak tumbuh atau kalus muncul tetapi belum bisa dihitung laju pertumbuhannya. Pada konsentrasi $0.5 \mu \mathrm{M}$ laju pertumbuhan terus mengalami kenaikan, pada 27 dan 30 hsi laju pertumbuhan sebesar $0.1 \mathrm{~cm} / 3$ hari kemudian mengalami kenaikan pada 33 hsi menjadi $0.237 \mathrm{~cm} / 3$ hari, pada 36 hsi menjadi $0.300 \mathrm{~cm} / 3$ hari. Laju pertumbuhan mengalami stagnansi pada $39-48$ hsi sebesar $0.350 \mathrm{~cm} / 3$ hari dan naik kembali pada 51 dan 54 hsi menjadi $0.462 \mathrm{~cm} / 3$ hari kemudian mengalami stagnansi.

Konsentrasi $1.5 \mu \mathrm{M}$ memiliki laju pertumbuhan pada $27 \mathrm{hsi}$ sebesar $0.075 \mathrm{~cm} / 3$ hari kemudian naik menjadi $0.112 \mathrm{~cm} / 3$ hari pada 30 dan 33 hsi. laju pertumbuhan mengalami kenaikan kembali menjadi $0.250 \mathrm{~cm} / 3$ hari pada 36 hsi dan mengalami stagnansi pada 3945 hsi sebesar $0.262 \mathrm{~cm} / 3$ hari, akan tetapi laju pertumbuhan terus meningkat pada 48 dan 51 hsi sebesar $0.512 \mathrm{~cm} / 3$ hari dan $0.887 \mathrm{~cm} / 3$ hari kemudian dihsi selanjutnya mengalami stagnansi. konsentrasi $0.5 \mu \mathrm{m}$ dan $1.5 \mu \mathrm{m}$ memberikan hasil laju pertumbuhan terbaik daripada konsentrasi yang lainnya dengan konsentrasi $1.5 \mu \mathrm{m}$ yang memberikan laju pertumbuhan tertinggi pada 51 dan 54 hsi sebesar $0.887 \mathrm{~cm} / 3$ hari. Konsentrasi 0.5-1.5 ppm menghasilkan kalus yang terus meningkat.

\section{Morfologi Kalus}

Indikator pertumbuhan eksplan pada kultur in vitro berupa warna kalus yang menggambarkan penampilan visual kalus sehingga dapat diketahui kalus yang masih memiliki sel-sel yang aktif membelah atau telah mati (Toharah et al., 2015). Aktivitas yang terjadi dalam sel akan membawa perubahan dalam keseluruhan bentuk dan stuktur baik pada tingkat organ maupun organisme (Taiz \& Zeiger, 2010). Morfologi kalus yang terbentuk pada penelitian ini menghasilkan kalus bertekstur kompak dan berwarna hijau ditunkukkan oleh perakuan $0 \mu \mathrm{M}+$ eksplan batang dan $0.5 \mu \mathrm{M}+$ eksplan batang. Kalus remah dan 
Jurnal Mangifera Edu, Volume 6, Issue 2, January 2022, 138-151

berwarna hijau kekuningan dihasilkan oleh perlakuan $0.5 \mu \mathrm{M}+$ eksplan daun dan $1.5 \mu \mathrm{M}+$ eksplan batang sebanyak 2 buah.

Hasil penelitian Fatmawati (2008) menyebutkan bahwa warna kalus menginduksi keberadaan klorofil dalam jaringan, semakin hijau warna kalus semakin banyak pula kandungan klorofilnya. Terjadinya perbedaan warna kalus disebabkan adanya perubahan pigmentasi yang dipengaruhi oleh nutrisi dan faktor lingkungan (Evans et al., 2020) selain itu, pencahayaan berperan dalam pembentukan warna kalus.

George (1993), menyatakan bahwa cahaya putih dapat merangsang pembentukan kalus dan organogenesis dalam kultur jaringan. BAP berperan dalam pembentukan klorofil pada kalus serta faktor lingkungan yaitu paparan cahaya sehingga kalus berwarna kehijauan (Muliati et al., 2017). Hal ini sesuai dengan penelitian Probowati \& Budi (2018) yang menyatakan bahwa pemberian BAP menghasilkan warna kalus yang hijau.

Morfologi kalus yang kedua yaitu tekstur kalus. Menurut (Indah \& Ermavitalini, 2013) menyebutkan bahwa tekstur kalus merupakan salah satu penanda yang digunakan untuk menilai pertumbuhan suatu kalus.

\section{SIMPULAN}

Terdapat pertumbuhan kalus timun apel pada 33 dan 36 hsi sebesar nilai $\mathrm{H}=6.355$ dan $\mathrm{H}=8.735$ serta pada 51 dan 54 hsi sebesar nilai $\mathrm{H}=7.080$ terhadap diameter kalus timun apel. Konsentrasi terbaik ditunjukkan pada $0.5 \mu \mathrm{M}$ dan $1.5 \mu \mathrm{M}$ yang memberikan pertumbuhan optimal terhadap laju pertumbuhan sebesar $0.462 \mathrm{~cm} / 3$ hari dan $0.887 \mathrm{~cm} / 3$ hari. Laju pertumbuhan tercepat ditunjukkan oleh perlakuan $1.5 \mu \mathrm{M}$ dan eksplan batang sebesar $0.316 \mathrm{~cm} / 3$ hari.

Penambahan konsentrasi BAP pada 0.5-3.0 dengan eksplan batang dapat digunakan sebagai acuan untuk menumbuhkan pertumbuhan kalus yang lebih baik, selain itu pengambilan ekslpan dilakukan pada saat musim kemarau agar mengurangi tingkat kontaminasi. 


\section{DAFTAR PUSTAKA}

Andaryani, S. (2010). Kajian penggunaan berbagai konsentrasi BAP dan 2, 4-D terhadap induksi kalus jarak pagar (Jatropha curcas L.) secara in vitro. Skripsi: Tidak Diterbitkaan

Ardiana, D. W. (2009). Teknik Pemberian Benzyl Amino Purin untuk Memacu Pertumbuhan Kalus dan Tunas pada Kotiledon Melon (Cucumis melo L.). Buletin Teknik Pertanian, 14(2), 50-53.

Argaloka, A. Y. (2013). Pengaruh kombinasi ZPT BAP dan 2, 4-D terhadap pertumbuhan kalus eksplan kotiledon akasia (Acacia mangium) pada media MS. Universitas Islam Negeri Maulana Malik Ibrahim.

Damanik, I. T. S., \& Siregar, L. A. M. (2017). Pengaruh Jenis Eksplan dan Komposisi Zat Pengatur Tumbuh Terhadap Induksi Kalus Pada Tanaman Binahong (Anredera cordifolia (Ten.) Steenis): The Effect of Explants Type and Growth Regulators Composition on The Callus Induction of Binahong (Anredera cordifo. Jurnal Online Agroekoteknologi, 5(3), 532-536.

Evans, D. E., Coleman, J. O. D., \& Kearns, A. (2020). Plant cell culture. Taylor \& Francis.

Fatmawati, T.A. (2008). Pertumbuhan Organ Tanaman Buah Naga Hylocerus undatus pada Medium MS dengan Penambahan BAP dan Sukrosa. Jurnal Natural Science, Vol 1 (1): 27-33.

George, E. F. (1993). Plant propagation by tissue culture. Part 1: The technology. (Issue Ed. 2). Exegetics limited.

Hafizh, L. T., Yenni, Y., Siregar, A. S., \& Maghfoer, M. D. (2019). Induksi Tunas Eksplan Batang Kultur Meristem Stroberi (Fragaria chiloensis) dengan Teknik Perendaman TDZ (Thidiazuron) Pada Kombinasi Media MS dan ZPT. Jurnal Produksi Tanaman, 6(7), 1442-1450.

Handoyowati, G. (2016). Ketahanan Kultur Kencur (Kaempferia galanga L.) Secara in Vitro pada Konsentrasi Sterilan dan Jenis Eksplan yang Berbeda. Universitas Muhammadiyah Purwokerto.

Harjadi, S. S. (2009). Zat Pengatur Tumbuh Pengenalan dan Petunjuk Penggunaan Pada Tanaman. Jakarta: Penebar Swadaya.

Heriansyah, P. (2020). Rahasia Mudah Menguasai Kultur Jaringan Tanaman: Teori dan Praktiknya. Jakarta: Lindan Bestari

Imelda, M., Wulansari, A., \& Poerba, Y. (2008). Shoot Regeneration from Leaf Petioles of Iles-Iles (Amorphophallus muelleri Blume). Biodiversitas Journal of Biological Diversity, 9(3).

Indah, P. N., \& Ermavitalini, D. (2013). Induksi Kalus Daun Nyamplung (Calophyllum inophyllum Linn.) pada Beberapa Kombinasi Konsentrasi 6-Benzylaminopurine (BAP) 
dan 2, 4-Dichlorophenoxyacetic Acid (2, 4-D). Jurnal Sains Dan Seni ITS, 2(1), E1E6.

Istiningdyah, A., Tambing, Y., \& Bustami, M. U. (2013). Pengaruh Bap dan Kasein Hidrolisat terhadap Pertumbuhan Tunas Melon (Cucumis melo L.) Secara In Vitro. Tadulako University.

Junairiah, J., Amalia N. S., Manuhara, Y. S. W., Ni'matuzahror N., \& Sulistryorini L. (2019). Pengaruh Variasi Zat Pengatur Tumbuh IAA, BAP, Kintin terhadap Metabolit Sekunder Kalus Sirih Hitam (Paper Bettle var Niagar). Jurnal Kimia Riset, 4(2), 121132.

Lestari, E. G. (2011). Peranan zat pengatur tumbuh dalam perbanyakan tanaman melalui kultur jaringan. Jurnal AgroBiogen, 7(1), 63-68.

Lugrasa, I. N., \& Tirta I. G. (2003). Studi Awal Penggunaan Beberapa Macam Media untuk Semai Biji Anggrek Alam Koleksi Kebun Raya Bali. Bali: Kebun Raya eka Bali.

Mardhiyetti. 2015. Pengaruh BAP (Benzil Amino Purine) dan NAA (Napththalen Acetic Acid) Terhadap Eksplan Tanamn Turi (Sesbania grandiflora) dalam Media Multiplikasi in Vitro. Jurnal Pastura, 5(1), 35-38

Muliati, M., Nurhidayah, T., \& Nurbaiti, N. (2017). Pengaruh Naa, Bap Dan Kombinasinya Pada Media Ms Terhadap Perkembangan Eksplan Sansevieria Macrophylla Secara in Vitro. Riau University.

Mustikawaty, P. N., \& Saputro, N. W. (2021). Induction of Apple Cucumber (Cucumis melo) Buds Development by Combination of Kinetin and IAA In B5 (Gamborg) Medium. Mangifera Edu, 6(1), 44-55.

Noviati, A., Nurcahyati, Y., \& Setiyari, N. (2012). Respon Pertumbuhan dan Produksi Senyawa Antioksidan pada Kalus Rosela (Hibiscus sabdariffa L.) dari Eksplan yang Berbeda secara in vitro BIOMA, 14(2), 85-90

Pramono, P. A. (2014). Induksi kalus jintan hitam (Nigella sativa L.) dengan menggunakan kombinasi zat pengatur tumbuh 2, 4-D dan kinetin melalui teknik kultur jaringan. Universitas Islam Negeri Maulana Malik Ibrahim.

Probowati, W \& Budi S.D. (2018). Callus Induction and Differentiation on Melon from in Vitro Cuture with The Addition of Indle Acetic Acid and Benzyl Amino Purine. Jurnal Agrosains, Vol. 6 (1): 15-21

Rahayu, T., \& Mardini, U. (2015). The Response of Node and Leaf Explant of Binahong (Anredera cordifolia L.) on MS Media with Variation of BAP Concentration. Proceeding Biology Education Conference: Biology, Science, Enviromental, and Learning, 12(1), 657-661.

Ramdan, R., Handaji, N., Beyahia, H., \& Ibriz, M. (2014). Influence of growth regulators on callus induction from embryos of five citrus rootstocks. Journal of Applied Biosciences, 73, 5959-5965. 
Risdianto, H., Setiadi, T., Suhardi, S. H., \& Niloperbowo, W. (2007). Pemilihan spesies jamur dan media imobilisasi untuk Produksi enzim ligninolitik. Prosiding Seminar Nasional Rekayasa Kimia Dan Proses, 132-135.

Sandra, I. E. (2019). Cara mudah memahami dan menguasai kultur jaringan skala rumah tangga. PT Penerbit IPB Press.

Sriyanti, D. P. (2000). Pelestarian tanaman nilam (Pogostemon heyneanus Benth.) melalui kultur mikrostek. Biosmart, 2(2).

Srikandarajah, S. E. P., Motyka, P. I., Dobrev, \& Serek,M. (2006). Regenerative Capacity of Cacti schlumbergera and Rhipsalidopsis in Relation to Endogeneous Phytohormones, Cytokinin Oxidases and Peroxidase Activities. J. Plant Growth Regul, 25: $79-88$

Sudiyanti, S., Rusbana, T. B., \& Susiyanti, S. (2017). Inisiasi Tunas Kokoleceran (Vatica bantamensis) pada Berbagai Jenis Media Tanam dan Konsentrasi BAP (Benzyl Amino Purine) Secara In Vitro. Jurnal Agro, 4(1), 1-14.

Sugiyama M. 1999.Organogenesis In Vitro Current Opinion in Plant Biology 2:61-64.

Sugiyarto, L., \& Kuswandi, P. C. (2014). Pengaruh 2, 4-Diklorofenoksiasetat (2, 4-D) dan Benzyl Aminopurin (BAP) Terhadap Pertumbuhan Kalus Daun Binahong (Anredera cordifolia L.) serta Analisis Kandungan Flavonoid Total (The Effect of 2, 4 Dichlorophenoxyacetic Acid (2, 4-D) and Benzyl Aminopuri.

Taiz, L dan Zeiger E. 2002. Plant Physiology. Sinauer Associates. Sunderland

Toharah, N. I., Jekti, D. S. D., \& Zulkifli, L. (2015). Pertumbuhan Kalus Daun Melon (Cucumis Melo) Varietas Mai 119 dengan Pemberian Bap (Benzyl Amino Purine) dan 2, 4-d (2, 4 Dichlorophenoxyacetic Acid). Jurnal Penelitian Pendidikan IPA, 1(2).

Uzun S, Ilbas A. I., Ipek, A., Arslan, N., \& Barpete, S. (2014). Efficient in Vitro Plant Regeneration From Immature Embryos of Endemic Iris sari and I. schachtii. Turk. J. Agric. 4.(38): 348-353

Widiyastuti, L. O. (2015). Induksi kalus pada eksplan batang tanaman binahong (Anredera cordifolia) secara in vitro dengan konsentrasi 2, 4-D dan BAP yang berbeda. Universitas Muhammadiyah Surakarta.

Yusnita. (2003). Kultur Jaringan: Cara Memperbanyak Tanaman Secara Efisien. Jakarta: Agromedia Pustaka.

Yuwono, T. (2012). Bioteknologi Pertanian. Yogyakarta: Gadjah Mada University Press. 